УДК 821.163.41.08 Поповић J. С.

$811.163 .41 ' 367.625 .43$

https://doi.org/10.18485/msc50.2021.2.ch22

Љиљана Суботић

\title{
ПАРТИЦИПИ У ФУНКЦИЈИ ТЕРМИНА У КњИЖЕВНОМ ЈЕЗИКУ ЈОВАНА СТ. ПОПОВИЋА
}

Поред многих проблема које је, на почетку 19. века, у оквиру стварања и стандардизације књижевног језика, морао решавати српски народ, питање терминологије заузимало је веома значајно место - поготово у Србији. То је потпуно разумљиво када се има у виду да је српском друштву, на прагу модерног доба, после успешно окончаних устанака, требало, готово одједном, створити терминологију за све видове друштвеног живота, пре свега за администрацију и образовање. О овим проблемима у нашој науци писано је у неколико наврата, мада сви аспекти проблема̄ стварања терминологије, чини се, нису још сагледани.

Међу српским интелектуалцима била су присутна, углавном, два схватања. Једно од њих, везује се, у првом реду, за име Вука Караџића, а друго, управо, за име Јована Стерије Поповића. Као што је већ познато, Вук је сматрао да конкретна појединачна решења у творби речи треба препустити појединцу, док је Стерији било знатно ближе схватање да би послове на изради терминологије (називословних речи) требало поверити организованим институцијама које би својим угледом, поред осталог, доприносиле и усвајању предложених решења. С таквим циљем je, као основним, уосталом, и основано Друштво српске словесности, касније Српско учено друштво. Тако Стерија у својој расправи Разлози о назывословнымғ рұчма, у Гласнику Друштва српске словесности из 1847. године каже: „Г. Вукъ Караџићъ изрази се и устмено и писмено, да дружство, занимаюћи се овымъ посломъ ништа друго не чини, него само квари и грди нашъ єзыкъ. - За чудо! кадъ прость човекъ каже псоглавъ, брзоплетъ, виторогъ, онда се єзыкъ не квари, а кадъ ученъ напише водопадъ, предуписъ, редоставъ; онда се єзыкъ квари и грди. (...) Дакле прости имаю право богатити єзыкъ новыма ръчма; ученъ, поне Србинъ, то не смъ, зашто онъ по ръчма Г. Вука не уме мыслити у свомъ єзыку! Найпослє заключи се вишиномъ гласова, да се престане одъ далъ- 
га кованя назывословны рбчій, и да то чине поєдини люди, а не дружство. Я нисамъ онда быо овога мнънія, и зато желимъ моє разлоге явно овдъ саобштити. (...) у дружству, гдъ су сви ови учительи заєдно, и свакій има прилике и своє основе наводити, и туђе саслушати, гдъ осимъ тога има и други людій, кои уму своє разлоге представити; гдъ се све, што $є$ дружство нашло, двапуть три решета и претреса, и цъломъ народу саобштава; и найпослє, гдъ свакій Србинъ има право гласа и мнънія: ту $\epsilon$ предпоставити, да ће и ръчь згодніє быти изражена; па да ће на овай начинъ пређе постати свеобштомъ, свепознатомъ. А кадъ $є$ єдномъ ръчь у употребленію, и постане обште познатомъ, онда ће се сродити съ нама;..." $(9-10,16)$.

Стерија је био принуђен, као и многи интелектуалци тога времена, да и сам, у појединим својим делима ствара одговарајуће термине. Поред, у науци доста добро познате Стеријине делатности у вези са овим проблемом, сачуване нам и у Гласнику ДСС из 1847. године, Стерија је и у неким другим својим делима трагао за решењима која су му се учинила најадекватнијим. У овом погледу истиче се, на пример, и његова тек постхумно објављена Реторика (приредила Иванка В. Веселинов у Зборнику историје књижевности, књ. 9, Београд, 1974, 539-628).

Приснији контакти српских интелектуалаца са рускословенским и славеносрпским језиком, стварани током школовања и каснијим сусретима са писаном речју, остављали су, несумњиво, утицаја у њиховим трагањима за одговарајућим терминолошким решењима. Сасвим је разумљиво што га налазимо и код Стерије за кога је познато да је у млађим годинама писао славеносрпским, а и касније га је употребљавао са посебном стилском вредношћу (у својим комедијама).

Арсеналу изражајних средстава које народни језик готово да није имао, припадале су форме, веома фреквентне у ранијим типовима књижевног језика, а које представљају континуанте некадашњих партиципа.

Судбина партиципа у књижевном језику код Срба у 19. веку није још довољно проучена, тим пре што и неки новији резултати оваквих истраживања нису још објављени (том проблематиком се и сама бавим). Овом приликом биће речи о присуству некадашњих партиципских форми у функцији термина, односно, о њиховој самосталној (супстантивизираној) употреби као термина и њиховој употреби у устаљеним синтагматским везама у функцији номинације.

Грађу за овај рад узимала сам из ових Стеријиних дела: Бој на Косову, 1828. г., Скендербег, 1828. г., Наод Симеон, 1830. г., Винко Лозић, 1830, 1832, 1835. г., Реторика, 1841-44. г., Стеријини текстови из Гласника ДСС, 1847. г., Сан Кратьевића Марка, 1848. г. и Ајдуци, 1853. г. Као што се види 
из управо наведеног списка, ексцерпирала сам грађу из дела, за које се, с обзиром на језик или тематику, могло очекивати да ће се у њима наћи овако употребљени партиципи. Њих је, наравно, из разумљивих разлога, највише у Стеријиној Реторици.

Ево неколико основних резултата:

У књижевном језику код Срба у 19. веку, раздобљу којем историјски и књижевно-језички припада и Стерија, налазимо, под утицајем рускословенске, односно славеносрпске традиције, релативно живу и стабилну употребу деклинабилних облика континуаната старословенских партиципа презента активног и пасивног и партиципа претерита активног. Ови партиципи се срећу у атрибутској функцији у којој, поред попридевљених форми, налазимо и праву партиципску употребу када партиципи фунгирају као кондензатори развијеног реченичног садржаја (наводим, наравно, само Стеријине примере):

- $\quad$ сви се садъ уредно ставе на равной поляни, (...), кад’ Алманзора к ньима долазетьа упазе (Бој на Кос., 1828, 45).

Поред атрибутске, срећу се и партиципске форме употребљене у копредикатској функцији:

- Миланъ поредъ свое жертве недвижимъ остане (Бој на Кос., 15), затим у предикатској функцији:

- Фигуре ове односе се поглавито на желю и страсти и єсу слъдуюће (Pem., 3б., 1841-44, 584) и,

и као супстантивизиране форме:

- Нећу те дуго обтерећивати прошавша ти приповедаюћи (Наод Симеон, 1830, 2).

Атрибутска функција је најзаступљенија од свих, а од форми партиципа, најчешћи су облици партиципа презента активног на -ћu. У овој функцији, поред праве партиципске употребе, срећемо велики број примера у којима је партицип већ попридевљена категорија и јавља се као квалификатор уз именску реч, односно, са њом образује слободну синтагматску везу:

- $\quad$ и башь се небо заклело на мое гореће молбе уво не приклонити (Haod, 183ǔ, 1).

у терминолошкој употреби, партиципи се срећу, најчешће, у устаљеним синтагматским везама. Ове везе-термини у говору учествују као целине и у функционалном погледу еквивалентне су речима. У устаљеним синтагматским везама у функцији номинације, облик пар- 
тиципа семантички је неодвојив од именице уз коју стоји и заједно са њом именује појам нечега као целину. Партиципски облик, у овом случају, сам по себи је ирелевантан. У слободним синтагматским везама, однос именице и попридевљеног партиципа арбитраран је, док је за овакве терминске везе потребно да буду посебно регистроване у лексикону.

Поред синтагматских веза у функцији номинације типа:

- забуну кодъ учеће се младежи порађаюћи (Глас. ДСС, 1847, 11),

- Число бесъдуюћи лица не смъ быти велико (Рет., 36., 1841-44, 595),

- Сарказамъ, т.є. уєдаюће руганъ (ibid., 586);

забележене су и форме супстантивизираних партиципа у терминолошкој употреби, нпр.:

- $\quad$ єръ као што у устменомъ говору много обстоятелства има коя бесъдуюћемъ помажу (ibid., 594);

- Писмо є говоръ къ одсуствуюћемъ єдномъ или више лицама управльный (ibid., 597),

- Метонимія быва: кадъ се меће садржеће мъсто садржимогъ (ibid., 578).

Употреба партиципа као номиналне речи могла је да буде изведена једино из атрибутске функције овог облика, тј. у овом случају, из синтагматских веза у функцији номинације. До функционалне супстантивизације придевске речи уопште, а у овом случају и вербидске форме, партиципа, долази, вероватно, преко претходне семантичке идентификације именице, тј. номиналне речи, са њеним квалификатором, атрибутом. Поистовећујући се са значењем свог атрибута, именска реч постаје синтаксички редундантна, ступа у неку врсту релативног односа са својим модификатором (у дубинској структури она се и реконструише односном реченицом: онај који / оно које ... итд.), те, губећи се са лексичког плана исказа као синтаксичко-семантички плеоназам, она предаје своју функцију, стожера номиналне фразе, свом модификатору - придеву, тј. партиципу.

У Стеријиним текстовима, поготово оним из млађих дана, употреба партиципских облика сасвим је уобичајена. С тога, донекле, изненађује чињеница да се овакви облици релативно ретко срећу у функцији термина, а поготово доследно, у оваквој употреби бележила сам форме партиципа презента активног на - $и$. Поред облика на - $и$ нађен је само један облик партиципа презента пасивног (Метонимія быва: кадъ се меће садржеће мъсто садржимогъ), док партицип претерита активни није уопште забележен. 
Од укупно 47 примера са партиципима у функцији термина, колико је регистровано у изабраном корпусу, 25 су синтагматске везе у функцији номинације, а супстантивизираних форми има 22. У оквиру устаљених синтагматских веза, као стожери номиналне фразе појављује се 13 различитих именица. То су пре свега именице које у свом значењском потенцијалу имају одредницу човек (лице, младеж, свет, општина). За конкретне именице налазимо по две потврде и то: уз именицу животиға (Китъ принадлежи сисаюћимъ животиняма; 36. 557) и уз именицу извор (Одъ се по собама (...) скакутьи извори дижу (источници); Бој. 1828, 25). Бројни су примери именских речи из логичке терминологије (противно, доказателство, причина, став) које се више пута понављају у корпусу, а забележен је по један пример уз именице реч, черта и ругаюе.

Као квалификативи уз набројане именице јавља се 15 различитих глаголских лексема од укупно 22 глагола забележених у свим примерима. Ако се приступи семантичкој анализи глагола, не види се неки посебан, кохерентан микросистем. То су форме комуникативних, интелектуалних, психо-физиолошких радњи и егзистенционални глаголи ((много)звечећи, увъраваюћи, совътуюћи, бесъдуюћи; дъйствуюћи, читаюћи, учећи се; высећи, узбуђуюћи, уєдаюћи, скакутьии, сисаюћи; лишаваюћи, одликуюћи, отсуствуюћu). Ови глаголи се срећу и у функцији персонификације уз именске речи које означавају неживо (причина, противно, реч, черта).

У супстантивизираним примерима срећемо 22 примера са укупно 10 различитих глаголских лексема у партиципском облику. Једино се глаголи беседити, одсуствовати и дејствовати јављају у оба типа термина, тј. и у оквиру синтагматских веза и као супстантивизирана форма. И овде заступљене глаголске лексеме могли бисмо, шире гледано, сврстати у наведена четири семантичка микросистема: комуникативни глаголи (говорећu, пытаюћu, бесъдуюћu), глаголи интелектуалних радњи (дъйствуюћu), глаголи психо-физиолошких радњи (чуюћи, (пред)идуће, посльдуюће, умирући) и егзистенционални глаголи (садржеће, садржимо, одсуствуюћи).

Партиципи у устаљеним синтагматским везама долазе као квалификативи уз агенсе којима је заједничка семантичка одлика општост. Супстантивизиран је онда када се недвосмислено односи на човека и трансформише се односном реченицом: онај који..., ако већ не постоји усвојени (страни) термин. Други случај супстантивизације је када би се као управна реч јавио појам који можемо трансформисати као оно шmo/ све штон...

Стерија је, употребом партиципа, покушао да створи термине за појмове за које наш језик и до данас није нашао аутохтоно лексичко ре- 
шење, већ се служи перифрастичним облицима (за пьтаюћiй, последуюћи, садржећи) или страним речима (за дъйствуюћій, одликуюће черте, уєдаюће руганъ и сл.). Међутим, ове Стеријине креације, па и остали примери у функцији номинације остали су ограничени и на нивоу његовог идиолекта. Изузетак су можда везе: учећа се младеж и читајућа општи$\mathrm{Ha} / \mathrm{cвет}$ које су имале ширу употребу у књижевном језику 19. века и могу се сматрати тада прихваћеним терминима.

Примери за устатене синтагматске везе у функиији номинације:

- Число бесъдуюћи лица не смъ быти тако велико (36., 595)

- Збитіє - (...) в) по цъли дъйствуюћи лица (3б/609)

- Обраћанъ (...) кадъ (...) отсуствуюћемъ тицу говоримо (36. 582)

- Кить сисаюћимғ животиняма принадлежи (36. 557) (2 х)

- скакутьій источницьь од' сви страна воздухъ чисте (Бој, 25) (2x)

- Сарказамъ, т.є, уєдаюће руганъ $(36,586)$

- забуну кодъ учеће се младежи порађаюћи (Глас. ДСС, 11)

- кодъ кога є читаюћа обштина велика (Глас. 16)

- читаюћемъ свъту саобште (Глас. 22) (2 х)

- доказателства (...) зову се увърраваюћа, а у другомъ пакъ совътуюћа (36. 558) $(2 \mathrm{x})$

- доказателства (...) страсти узбуђуюће (36. 542)

- Одликуюће черте (36.590)

- Мустословіє єсть скупъ многозвечећи рвчій, безъ смисла (3б. 573)

- Противно може быти (...) в) тишаваюће (...), као: животь и смрть (36. 553)

- Причина дъйствуюћа (3б. 553) (3 х)

- Кадъ се овакови ставови попуне, зову се періодъ сложеный, кои толико членова може имати, колико высећи ставова има (36. 588).

Примери за супстантивизиране партиципе у функиији термина:

- Олицетвореніє (...) састои се у томъ, кадъ недушнымъ стварма (...) своиства душны створеня придевамо, (...), да се као дъйствуюћа, чуюћа и говорећа представляю (36. 579)

- Метонимія быва: 1, кадъ се предидуће мъсто оногъ меће, што сльдує (36. 578)

- Искуствена или изврнута Хрія єсть двояка: 1, чрезъ предидуће и послъдуюће (36. 565) (5 x)

- Метонимія быва: кадъ се меће садржеће мъсто садржимогъ (36. 578)

- $\quad$ или кадъ люди, кои су преминули, као дъйствуюће приводимо (Ibid. 579) 
- Сарказамъ, т.є. уєдаюће руганб према умирућемъ (Ibid. 586)

- $\quad$ онай кои се пыта, вопросима принуђенъ быва на она понятія долазити, коя пытаюћій жели да кодъ нъга произведе (36. 596)

- Писмо є говоръ къ одсуствуюћемъ єдномъ или више лицама управлъный (Ibid. 628)

- будући да говорникъ као свакій дъйствуюћiй има нъке (...) знаке (Ibid. 628)

- Писменый Разговоръ разликує се од устменогъ (...); єръ као што у устменомъ говору много обстоятелства има коя бесъдуюћемъ помажу... (36. 594).

\author{
Ljiljana Subotić \\ LES PARTICIPES EN FONCTION DE TERMES TECHNIQUES DANS LA LANGUE \\ LITTÉRAIRE DE JOVAN STERIJA POPOVIĆ
}

Résumé

$\mathrm{Au}$ dix-neuvième siècle les Serbes navaient pas encore résolu maints problèmes relatifs à la langue littéraire, dont aussi la question importante de la terminologie. Tout comme la plupart des intellectuels de l'époque, Sterija était oblige, de forger lui-même, dans certaines de ses oeuvres, les termes techniques correspondants. Il les puisait, entre autres, dans la mine de moyens d'expression dont la langue populaire était presque totalement dépourvue, c'est-à-dire dans les participes qui étaient très fréquents dans les types antérieurs de langue littéraire. Dans loeuvre de Sterija on rencontre des participes dans les rapports syntagmatiques figés, en fonction de nomination ou en tant que participes substantivisés, employés comme termes techniques. En ayant recours aux participes, Sterija a essayé de créer des termes techniques pour lesquels notre langue, n’ayant pas encore trouvé de solutions autochtones, se sert de formes périphrastiques ou de mots étrangers. Toutefois, les exemples de ce genre sont relativement peu nombreux et ils sont restés, en general, limités et au niveau de son idiolecte. 